\title{
NADIA Copyright Transfer Form
}

\section{Corresponding Author's Information (please print):}

Name:

Email Address:

Institute Affiliation:

Address:

Title of the Paper:

Name of Journal:

\section{LICENSE AND COPYRIGHT AGREEMENT:}

The Corresponding Author(s) hereby declare and agrees that:

I. The Corresponding Author(s) warrants that their contribution is original, except for such excerpts from copyrighted works as may be included with the permission of the copyright holder and author thereof, that it contains no libelous statements, and does not infringe on any copyright, trademark, patent, statutory right, or propriety right of others. The Author(s) signs for and accepts responsibility for releasing this material on behalf of any and all coauthors.

II. The Author(s) may not publish his/her contribution anywhere else without the prior written permission of the publisher unless it has been changed substantially.

III. If any plagiarism found in camera-ready article after Publication, the corresponding author is solely responsible not NADIA or NADIA Editorial Boards.

IV. This transfer of copyright gives NADIA the rights to develop, promote, distribute, and archive a body of scientific works throughout the world.

V. The undersigned corresponding author, also certify that he/she have the consent of each author to transfer and assign any and all rights, title, and interest, including copyright of the article referred above. The corresponding author hereby assign and transfer to the NADIA copyright and all rights under it in the event that such work is published by the NADIA. The corresponding author further confirm that this article has not been published elsewhere, nor is it under consideration by any other publisher.

VI. In return for these rights: NADIA agrees to publish the identified contribution at his own cost and expense. Resale of such copies is not permitted.

The undersigned hereby given permission to NADIA to publish the above contribution to the above mentioned Journal.

Date:

Corresponding Author's Signature: 